\title{
'Heerloese knechten': Unemployed Soldiers as a Security Threat in the Sixteenth-Century Netherlands
}

\author{
ERIK SWART
}

Erik Swart completed his $\mathrm{PhD}$ at the University of Amsterdam in 2006. He subsequently lectured at that university and at Utrecht University. In 2007-2008 he was a Postdoctoral Fellow at Antwerp University. He is currently a postdoctoral researcher at the JustusLiebig-University in Giessen within the DFG Collaborative Research Centre/Transregio 138 'Dynamics of Security. Types of Securitization from a Historical Perspective'. His main interest is in the history of the sixteenth- and seventeenth-century Netherlands from a comparative and international perspective. Among his recent publications is 'Defeat, honour and the news. The case of Breda (1625) and the Dutch Republic', European History Quarterly 4 6 (2016) 6-26.

\begin{abstract}
The sixteenth century saw increasing problems with disbanded, unemployed soldiers ('heerloese knechten') in Europe. In the Holy Roman Empire they had by the middle of the century come to be regarded as the primary threat to the Eternal Public Peace (Landfrieden). This article looks at why and how unemployed soldiers became a security threat in the sixteenth-century Netherlands. It does so by analysing the developing discourse on this topic and the measures taken to combat the threat in comparison with the Empire. In practice both the Netherlands and the Empire developed a collective security regime, which depended on cooperation to maintain the peace against threats like unemployed soldiers. There is, however, no contradiction here with rulers extending their grip on their territories. But there is a clear difference between the Netherlands and the Empire. Within the latter, an appeal to the Landfrieden allowed the implementation of supra-territorial, regional security policies, from 1555 in the Imperial Circles. For the Netherlandish provinces, on the other hand, such policies for combating the unemployed soldiers remained elusive, even under the Union of Utrecht of 1579.
\end{abstract}

Keywords: lordless soldiers, history of security, labour history, rural militias, passports

DOI 10.18352/emlc.128 - URL: http://www.emlc-journal.org

Publisher: Stichting EMLC, supported by Utrecht University Library Open Access Journals | The Netherlands Copyright: The Author(s). This work is licensed under a Creative Commons Attribution-NonCommercial 4.0 International License. 


\title{
'Heerloese knechten': Unemployed Soldiers as a Security Threat in the Sixteenth-Century Netherlands
}

\author{
ERIK SWART
}

On 19 February 1555 the peasants of Oldebroek wrote a desperate letter to the Court of Guelders, since its creation by the Habsburgs in 1544 the judicial and administrative centre of the province. They were beset by numerous 'heerloese knechten' and other miscreants, who stole their food and poultry and threatened them with knives and fire when they complained. The peasants knew no one else to ask for protection than the Court, which represented their lord, the Habsburg Emperor Charles v. ${ }^{1}$ These 'heerloese knechten' were lordless, in other words unemployed, soldiers. In the Holy Roman Empire, of which the Netherlands were officially still a part, they had by the middle of the sixteenth century come to be regarded as the primary threat to the Eternal Public Peace (Ewiger Landfrieden) of 1495. By 1555, no fewer than twenty articles of the new Reichsexekutionsordnung, which attempted to institutionalize the Peace, explicitly or implicitly dealt with the Gartknechte, as they were often called in German. ${ }^{2}$ Clearly, they were considered a threat to security in the Empire. But the letter sent by the Oldebroek peasants shows they also caused problems in the Netherlands, although this has hitherto not been investigated. ${ }^{3}$

The aim of this article is to analyse unemployed soldiers as a security threat in the sixteenth-century Netherlands. Although the concept of 'security' was at that time not as common as it is today, it was still of central importance. Early modern Europe is replete with discourses of threats and practical attempts to find political solutions to them. One of the primary conditions for the functioning of society was that rulers and subjects had concluded a reciprocal agreement, in which rulers provided security (Schutz und Schirm) in exchange for the recognition of their right to rule and the provision of advice and help. This makes security a structural feature of early modern societies which helped legitimise power and a claim to a monopoly on violence. Since this security, in the form of protection, depended in practice on the fulfilment of this tacit agreement, it was far from stable, and

1 Arnhem, Gelders Archief (hereafter AGA), Hof van Gelre en Zutphen, 986, no. 1407.

2 Carl, 'Landfriedensbrecher', 276, 283-284; Reusch, “"Bedrohliche Mobilität”'; Baumann, Landsknechte, 131-134; Burschel, Söldner, 274-283; Weber, 'Landfriedenspolitik im Schwäbischen Kreis', 194-195.

3 Behr, 'Garden und Vergardung', which contains numerous references to the Netherlands and lordless Netherlandish soldiers causing trouble. 
had to contend with alternative visions of the existing order and competing providers of protection. ${ }^{4}$

In analysing unemployed soldiers as a security threat in the sixteenth-century Netherlands I will not employ an a priori, essentialist definition of 'security', but look at how a social problem was turned into a security problem, and at the political consequences. In Critical Security Studies the somewhat awkward concept of 'securitization' has been coined for this process. ${ }^{5}$ The aim is to contribute to an understanding of what security meant at the time and what concrete problems were dealt with in such contexts. This entails analysing any relevant discourse, in this case the one on lordless soldiers, but also the measures that were taken in practice. In other words, this article will match normative legislation against daily reality. Violence, for instance, was not always an effective way to create security. Although it has clear links with security, the employment of violence may well prove counterproductive, and result in greater insecurity. In Security Studies this is known as a security paradox. An appeal to the law and social norms often promised more enduring results and security. ${ }^{6}$

The central question of this article, then, is why and how unemployed soldiers became a security threat in the sixteenth-century Netherlands. The first section deals with the development of the discourse on lordless soldiers in normative legislation from the late fifteenth until the early seventeenth century, in which they were branded both a political and a moral threat. The next three sections analyse the daily reality of coping with unemployed soldiers, focusing on the use of passports as a means of control and regulation, the roles of local officers (sheriffs, bailiffs, judges), and attempts at self-defence by the rural population, which was most threatened. Walled cities, being enclosed communities, generally found it easier to control and regulate access, and expel unwanted elements.

The Holy Roman Empire is the primary frame of reference for developments in the Netherlands, since the subject of unemployed soldiers has been well-studied here and the Empire had close links to the Netherlands. Although their political ties with the Empire were loosened in 1548, the Netherlands remained an official part of it until 1648. The estates in the Netherlands had a position similar to estates in the Empire. Using the Empire as a reference allows us to see what was typical for the Netherlands and what was not. The comparison will level differences and show the Netherlands to be different but comparable. The Netherlandish counterpart to the Landfrieden was the common peace (gemene ruste). ${ }^{8}$ The problem of unemployed soldiers existed elsewhere in Europe as well, but since far less research has been conducted into this topic here, further comparisons are difficult. ${ }^{9}$

4 Schorn-Schütte, 'Sicherheit als Begriff, 43-44; Carl, Babel, and Kampmann, 'Einleitung'; Carl, 'Einleitung in die Sektion', 267-268; Stauber, 'Einführung', 90; Gunn, Grummitt, and Cools, War, State, and Society, $244-247$. 5 Buzan and Hansen, The Evolution, 212-217; Fierke, Critical approaches, 34, 253-266; Carl, Babel, and Kampmann, 'Einleitung'; Conze, Geschichte der Sicherheit, 82-101.

6 Carl, Babel, and Kampmann, 'Einleitung'; Carl, 'Einleitung in die Sektion', 265-266; Booth and Wheeler, 'Uncertainty', 138.

7 Carl, 'Kollektive Sicherheit und föderative Ordnung'.

8 Devillers, Inventaire analytique d'Hainaut, I, 158, 6 July 1535: 'le bien, repos, transquillité et seurté des pays de par-deçà'. For the gemene ruste, see for instance Van Loon, Gelders placaet-boeck, I, 340-343, Decree of 14 December 1566.

9 See for instance Hale, War and Society in Renaissance Europe, 87-89, 108-109; Tallett, War and Society in Early Modern Europe, 140-141, 145-147; Beier, Masterless men, 93-95. 
The main sources this article relies on to analyse the discourse on unemployed soldiers are the ordinances and decrees of the Habsburg authorities. For the reality on the ground a wider range of sources was employed, including contemporary histories and chronicles. The archives of the Court of Guelders in Arnhem proved particularly useful. Its correspondence and surviving case files shed a clear light on problems with unemployed soldiers. I was unable to locate similar sources in other provinces. In Brabant, the provincial archives were destroyed in 1695 when the French bombarded Brussels. I only found a few relevant cases from $1567 .{ }^{10}$ The material available for Flanders contained many references to men convicted as vagabonds, but did not provide their background. Since Flanders was an important source of soldiers, it is almost inconceivable that there were no unemployed soldiers amongst them. ${ }^{11}$ The archives of the Court of Holland also yielded very little on problems with 'heerloese knechten', merely two sentences from 1544$1545 .{ }^{12}$ Although as a result, evidence from Guelders is overrepresented in this article, it is unlikely that the situation elsewhere in the Netherlands was structurally different. The snippets found in Holland and Brabant, and the other sources used, confirm this. It should also be borne in mind that soldiers were very mobile and travelled considerable distances. In 1545 a brewer from Borgloon in the Prince-Bishopric of Liège ended up in Guelders via Antwerp, Gouda, Utrecht, Amsterdam, Zwartsluis, Meppel, and Vollenhove, always following rumours that soldiers were being hired elsewhere. ${ }^{13}$

\section{The Discourse on Unemployed Soldiers}

Unemployed professional soldiers - unemployed mercenaries if you will - were no new problem in the latter half of the fifteenth century. They had in fact existed for centuries. ${ }^{14}$ Standing armies did not exist until the second half of the seventeenth century. Before that time, forces were raised when a war began and dismissed at the end of the conflict, making large numbers of men accustomed to war and violence redundant. In fact, since waging war was a seasonal business taking place in spring and summer, many soldiers found themselves temporarily unemployed even during a conflict. They were dismissed at the end of the campaigning season and rehired at the start of the next one, in the words of the Habsburg government in December 1521 'to avoid the cost of their pay during this winter'. ${ }^{15}$ The

10 Brussels, Rijksarchief Vorst (hereafter Rav), Archief van de Drossaard van Brabant en Provoost van het Hof, 253, cases dated 5-6 January and 8-9 May 1567.

11 Courtrai, Rijksarchief (hereafter RAK), Archieffonds D'Ennetières, 660, Registre vander compositie vanden Souverain Baill, 1544-1551; RAK, Archieffonds D'Ennetières, 661, Accounts on 1554-1569; RAK, Archieffonds D' Ennetières, 662, cases dealt with in 1555-1558; Gunn, Grummitt, and Cools, War, State, and Society, 296-297. 12 The Hague, National Archives (hereafter NA), Hof van Holland, 5654, fols. 124, 158; NA, Hof van Holland, 3547, fol. 98r; NA, Hof van Holland, 3551, fol. 174r; NA, Hof van Holland, 3546, fols. 52, 105 r.

13 AGA, Hof van Gelre en Zutphen, 4524, dossier 1545/2.

14 Kintzinger, 'Brigands'; Contamine, La guerre en Moyen Age, 396-404; Schnerb, 'L'honneur de la maréchaussée', 170; Mallett, 'Mercenaries', 215-216; Nicholson, Medieval warfare, 57.

15 Receuil des Ordonnances des Pays Bas (hereafter ROPB), II, 127, Decree of 16th December 1521: 'pour éviter les fraiz de la soldée d'iceulx durant ceste yver'. See also RopB, vi, 4, Decree of 7 November 1543. 
problem was aggravated by the increasing scale of warfare from the late fifteenth century. The armies raised gradually became larger: the 1557 estimate of fifty-two thousand troops necessary in the Netherlands to fight the French was probably the biggest army up to that date. Around 1595, some ninety thousand troops served in the Netherlands, around sixty thousand in the Habsburg army, the remainder served the States-General. ${ }^{16}$

Especially after circa 1450 , it is clear that the manner in which unemployed soldiers were regarded and dealt with in the Empire began to change. The term Gartknecht first appears in this period. Both at the imperial and territorial level the authorities increasingly portrayed them as a social and moral threat. The Reichsexekutionsordnung of 1555, mentioned above, in many ways was the culmination of this process. The Gartknechte were deemed a lordless and mobile group of (potential) criminals and idlers. In other words, they lived outside the existing social order, defying social control, which made them a threat to that order. They were also deemed to have no honour. With the advent of the Reformation they were additionally framed as a political threat to the Emperor. Unemployed soldiers might after all be hired by his enemies and were now linked with conspiracies and revolt. Furthermore, in the course of the sixteenth century they were gradually merged with other vagrant marginal groups who were considered a threat, like vagabonds, beggars, and gypsies. By circa 1590 this development had been completed in the Empire. ${ }^{17}$

On the whole, the discourse on unemployed soldiers in the Netherlands seems to have followed that in the Empire, but with some differences. The term Gartknecht had no direct equivalent here, but from the late fifteenth century onwards the verb garden (gaerden) was employed in the meaning of living off the rural population by begging for food and shelter, particularly in relation to unemployed soldiers. An early mention appears in a chronicle written in Den Bosch and relates to a discussion in the States of Brabant in $1494 .{ }^{18}$ The term was later widely used in anything from official documents to narrative sources and court testimonies. ${ }^{19}$ It is clear that unemployed soldiers were increasingly on the government agenda post-1500. A steady flow of decrees by the Habsburg authorities banned them from living off peasants and convents in the countryside without payment for what they consumed. The authorities ordered disbanded soldiers to return to their homes and trades instead. ${ }^{20}$ The term 'lordless soldiers' does not seem to occur before the 1540s. The decrees were promulgated in all Habsburg provinces, since the problem

16 Rinzema, Sicke Benninge, 258; Gunn, Grummitt, and Cools, War, State, and society, 80-82, 161-163, 288-289, 297; Tracy, The founding of the Dutch Republic, 31-32, 37-38. On the projected strength of 1557, see Brussels, Algemeen Rijksarchief (hereafter ARAB), Duitse Staatsecretarie, 112, fols. 39-40v, and ARAB, Duitse Staatsecretarie, 112, fols. 78-80; Parker, Army of Flanders, 231; Nickle, The military reforms, 192.

17 Huntebrinker, “'Gartknecht" und "Passport”, Reusch, “"Bedrohliche Mobilität"'; Nassiet, La violence, 180; Burschel, Söldner, 300-303, 308-309, 311.

18 Van Os, Kroniek van Peter van Os, 271.

19 Aurelius, Die cronycke van Hollandt Zeelandt, fol. 434r; Benninge, Croniken der Vrescher Landen, 490, 513; ROPB, VIII, 86, Instruction for the stadtholder of Guelders, 18 June 1560; AGA, Hof van Gelre en Zutphen, 4526, dossier 1561/2, Testimony of former soldiers, 10 March 1561; AGA, Hof van Gelre en Zutphen, 983, no. 228+, Stadtholder of Guelders to sheriff of the Veluwe, early June 1547.

20 Rорв, I, 61-62, 171-172, 280-281, 630, Decrees from 1508, 1511, 1513, and 1518; ROPB, II, 125, 130-131, 245-246, 330-331, 515-516, Decrees from 1521, 1522, 1524, and 1528; ROPB, III, 541-542, 563-564, Decrees from 1536; ROРв, IV, 12, 29-30, 335-336, 343-344, 388, Decrees from 1537, 1541, and 1542; ROPB, V, 4, 92-93, 408-409, 
occurred everywhere, from Flanders and Hainaut to Groningen. However, because Groningen only came under Habsburg rule in 1536, it continued to resist the edicts and what it perceived as Habsburg encroachment on its self-determination until the 1550 s. $^{21}$

As in the Empire, unemployed soldiers in the Netherlands were lumped together with other groups deemed threatening because they were lordless and mobile. They were almost immediately grouped with vagabonds and beggars, and by the middle of the century government circles saw the lordless soldiers simply as a subset of vagabond. When the stadtholder of Guelders, Philip of Lalaing, Count of Hoogstraten, was confronted with misbehaving unemployed soldiers in 1554, he referred to them as 'soldiers and other vagabonds'. In 1566 Governess-General Margaret of Parma likewise spoke of 'lordless soldiers, foreign and native beggars, vagrants and other vagabonds, tramps and idlers'. ${ }^{22}$ The association with criminal activities is also similar to that in the Empire. By 1564 the Habsburg authorities mentioned lordless soldiers in the same breath as 'blackguards, thieves, extortionists, murderers, and other scum'. ${ }^{23}$ These unemployed soldiers, existing as they did outside 'civilised society', were clearly considered both a social and a moral threat.

Developments in the Empire following the Reformation led to these soldiers being framed as a political threat, too. A decree from 1541 expressed the fear there might be Anabaptists among the unemployed soldiers, who would attempt to surprise a city or fortress. ${ }^{24}$ Apparently the Habsburgs feared a repeat of the Anabaptist take-over of Münster in 1534-1535. There was also a constant flow of decrees forbidding Netherlandish subjects of the Habsburgs entering the military service of foreign lords without permission. Emperor Charles v clearly feared they could serve his enemies, but he also wanted to maintain a reserve of men he could employ himself. In 1554 Charles required experienced Netherlandish soldiers for a number of regiments he considered raising, ordering that subjects were obliged to serve their own natural prince and fatherland before any other lord. ${ }^{25}$ These decrees were intended for all the Habsburg Netherlands and were used to prosecute offenders from Holland to Namur. In 1544-1545, even Netherlanders who in 1542-1543 had served in the last campaign of the Duke of Guelders against the Habsburgs,

Decrees from 1543, 1544, and 1548; ROPB, VI, 353, Decree from 1553; Gunn, Grummitt, and Cools, War, State, and Society, 278.

21 Postma, 'De mislukte missie', 10, 17, 20, 21; Van Loon, Gelders placaet-boeck, I, 16-18, Edict of 20 February 1545 .

22 AGA, Hof van Gelre en Zutphen, 642, no. 207, Hoogstraten to the Court of Guelders, 26 March 1554: 'les lansquenetz et autres vagabondes'; AGA, Hof van Gelre en Zutphen 658, no. 1855, Margaret of Parma to the stadtholder and Court of Guelders, 4 August 1566: 'herlose knechten vuytheymsche ende inheymsche bedelers, netteboeven, ende andere vagabonden, lantloopers ende ledichgangers'; Dauven, 'L'évolution des pratiques'.

23 AGA, Hof van Gelre en Zutphen, 4411, Instruction for member of the Court of Guelders, 1564: 'herloose knechten schelmen, dieven, knevelers, moerders und sunst allerley geboeffte'.

24 ROPB, IV, 343-344, Decree of 14 December 1541; Ruff, Violence, 232-233.

25 Van Loon, Gelders placaet-boeck, I, 152-153, Decree of 14 February 1554; Gunn, Grummitt, and Cools, War, State, and Society, 243-244; ROPB, IV, 335-336, Decree of 1541; ROPB, V, 58, 408-409, Decrees of 1544 and 1548 ; AGA, Hof van Gelre en Zutphen, 1049, no. 2000, Stadtholder to sheriffs of Guelders, 3 April 1554; AGA, Hof van Gelre en Zutphen, 810, no. 2395, Court of Guelders to Hubert van Buren, 17 July 1553. 
were prosecuted. ${ }^{26}$ Charles v's son Philip II continued in the same vein, in 1567 targeting discharged Netherlandish soldiers who were going to France and elsewhere to enlist. With the advent of the Dutch Revolt in 1566, joining the rebel forces was outlawed as well. ${ }^{27}$

Another indication that the unemployed soldiers were regarded as a political and moral threat was the disavowal of their self-appointed leaders by the Habsburgs. This was apparent by 1541 , in the qualification 'so-called captains'.$^{28}$ In the early decades of the sixteenth century gatherings of unemployed soldiers could amount to thousands. Often these were complete units that stayed together after their dismissal under their own captains and went looking for new employers. In 1517 a group of fourteen hundred discharged soldiers left Holland. By the time they reached Guelders territory on the river Meuse their numbers had swollen to around seven thousand men, and they offered their services to the Emperor and the King of England. Initially under three captains, their growing numbers meant they created an additional three. In 1526 another seven to eight thousand unemployed soldiers under two captains ('velthoeftlueden') arrived in Drenthe. ${ }^{29}$ From the Habsburg perspective the only acceptable captains and colonels were those commissioned or contracted by them. The result was that by the 1540 s it is certain that massive gatherings of thousands of unemployed soldiers no longer occurred in the Netherlands. They seem to have moved around in small groups of just a few men. Occasionally groups of around ten men are mentioned. A group of 150-200 mentioned in Guelders in 1554 seems to have been much rarer. ${ }^{30}$

With the beginning of the Dutch Revolt the frequency of decrees regarding the subject of lordless soldiers declined, as there were now plenty of employment opportunities, although any lull in hostilities followed by the disbanding of troops quickly saw the discourse resurface. Examples of this are the Habsburg decrees of 1567 and $1571 .{ }^{31}$ But even during hostilities there was the occasional use of the term 'lordless soldier' at the local level, with Zutphen ordering 'heerloze knechten' to leave in 1578 and $1600 .^{32}$ There is a distinct possibility that the city wielded the term to describe either soldiers who had left their

26 Gunn, Grummitt, and Cools, War, State, and Society, 244, 255; Arnhem, AGA, Hof van Gelre en Zutphen, 4524, dossiers 1544/1 and 1545/2 (soldiers who had served against Charles V in 1542-1543) and dossier 1547/4 (for the case against a citizen of Nijmegen for hiring troops for the landgrave of Hessen).

27 Loon, Gelders placaet-boeck, I, 348-350, Decree of 14 September 1567; Loon, Gelders placaet-boeck, I, 596599, Decree of 9 June 1572; Loon, Gelders placaet-boeck, I, 340-343, Decree of 14 December 1566; De Kempenare, Vlaemsche kronijk, 35 .

28 Rорв, IV, 343, Decree of 14 December 1541.

29 Aurelius, Die cronycke van Hollandt Zeelandt, fols. 434r-434v; Benninge, Croniken der Vrescher Landen, 513; Burschel, Söldner, 293.

30 AGA, Hof van Gelre en Zutphen, 985, no. 1333, Court of Guelders to the sheriff of the Veluwe, 29 November 1553; AGA, Hof van Gelre en Zutphen, 642, no. 15, Court of Guelders to the stadtholder, 3 May 1545; AGA, Hof van Gelre en Zutphen, 642, no. 207, Stadtholder to the Court of Guelders, 26 March 1554; Burschel, Söldner, 292-294.

31 Van Loon, Gelders placaet-boeck, I, 348-350, Decree of 14 September 1567; Van Loon, Gelders placaet-boeck, I, 441-442, Decree of 11 September 1571; Groningen, Groninger Archieven (hereafter GA), Inventaris van het archief van het Stadsbestuur van Groningen 1549-1815, appendix 2, Ordinance of Groningen, 28 May 1569 (copied in 1633); Alting, Diarium, 178.

32 Zutphen, Regionaal Archief Zutphen (hereafter raz), Archiefnummer 1, Decrees of 25 April 1578 and 19 October 1600. See for a similar approach in Groningen Alting, Diarium, 441, 452. 
units without permission or runaways. The conclusion of the Twelve Years' Truce in 1609, however, led to the discharge of substantial numbers of soldiers. The Habsburg army alone let go some ten thousand Netherlandish soldiers and more than sixteen thousand Germans in 1607-1609. The Dutch army dismissed around twenty thousand men in the same years. No wonder the States of the Quarter of Zutphen in Guelders saw fit to take renewed measures against 'lordless soldiers and vagabonds' in May 1609. ${ }^{33}$ Typically, in the United Netherlands this decision was now made by the local estates on their own initiative. The discourse involved, however, was that inherited from their former Habsburg rulers.

\section{Passports as a Means of Control and Regulation}

In the Empire the use of passports to control and combat the problem of Gartknechte developed at a territorial and imperial level during the first decades of the sixteenth century. In the Duchy of Cleves, for example, passports for legitimate soldiers are mentioned in 1535. In the Reichsexekutionsordnung of 1555, article thirty-six stipulated that soldiers needed a passport issued by their employer to prove they were not lordless and unemployed. However, these passports only became a success because the soldiers themselves could use them for their own purposes. Passports proved their skill and experience as professional wielders of weapons and violence, and showed they were honourable men whose behaviour had been in accordance with the norms laid down by the authorities. By the later sixteenth century dismissal without a passport had become a punishment soldiers feared. Passports were also increasingly used within armies during wartime to regulate behaviour, allowing authorities to distinguish between unauthorised absence from units and authorised leave. It should be noted however, that the absence of any agreement on their appearance made them relatively easy to forge. ${ }^{34}$

These developments in the Empire also obtain over a much wider area of Europe in roughly the same period. The King of France stated as early as 1462 that soldiers dismissed from service should receive a paper signed by the authorities and passports are also mentioned for French soldiers returning from service in Italy in 1508. In the Habsburg Netherlands a decree from 1511 mentions passports for soldiers. A passport from 1523 signed by the Duke of Guelders for a soldier quitting his service has survived. ${ }^{35}$ By 1543 the Habsburg authorities in the Netherlands specified that captains should not engage men who had served before without a passport; this was to prevent soldiers from leaving a unit and signing on elsewhere. This suggests that issuing passports to soldiers upon discharge became the norm. It is also evident that the passport became standard in wartime for

33 Parker, The Army of Flanders, 231; Nickle, The military reforms, 192; Egmond, Underworlds, 49-50; AGA, Staten van het Kwartier van Zutphen en hun Gedeputeerden, 1367, Commission of 4 May 1609: 'heerlosen soldaten ende vagabunden'.

34 Huntebrinker, "'Gartknecht” und "Passport”', 15-29; Carl, 'Landfriedensbrecher', 271, 285; Reusch, “"Bedrohliche Mobilität”', 214-215, 222-224; Burschel, Söldner, 311-312, 313-314.

35 Nordman, 'Sauf-conduits et passeports', 146, 148; RОРв, I, 171-172, Decree of 2 July 1511; Van Hasselt, Geldersche oudheden, I, 423, Passport of 12 May 1523. See for England: Beier, Masterless men, 142-144, 154. 
distinguishing unauthorised absences from authorised leave. A decree by Charles $\mathrm{v}$ from 1552 makes this very clear. ${ }^{36}$

In practice, matters seem to have been more complicated. A man who had served in the Habsburg forces that took Guelders in 1543 indeed possessed a passport issued upon disbanding of his unit; the passport has survived. Yet none of the unemployed soldiers apprehended for garden or suspected criminal activities and interrogated by the Court of Guelders in 1545, 1547, and 1560-1563 mention passports. Their interrogators did not inquire after them either. ${ }^{37}$ A serving soldier apprehended in Arnhem in 1552 was asked why he had no passport. He replied he reckoned he did not need one, since he had left the army near Luxembourg because he was ill and intended to return once he had recovered. This soldier, a citizen of Arnhem, thus shows awareness that passports were issued on dismissal, but interprets the necessity of passports during wartime differently than the authorities. He could have lied and simply have run away, of course. ${ }^{38}$ Figures concerning some units serving the Netherlandish rebels in the mid-1570s and early 1580 os indicate that although a large proportion of the soldiers leaving a unit did so with a passport (40 to 49 percent), the number quite simply disappearing could be almost as large ( 23 to 47 percent). ${ }^{39}$ It should be noted here that the term used to denote runaways in the province of Holland was 'schelm'. ${ }^{40}$ This derogatory term was not related to a specific act, but denoted a status, namely that of someone who had forsaken his honour.

That passports were nevertheless increasingly deemed necessary by soldiers is also indicated by the existence of fraud and other abuses. Some men paid to get a passport. In 1554 for instance a clerk of the pioneers had his hand cut off and was banished from the Emperor's lands in perpetuity for forging passports. But even captains indulged in the practice of issuing passports for payment. ${ }^{41}$ Colonels and captains also seem to have handed out passports to soldiers upon disbandment that licensed garden, perhaps as compensation for outstanding pay. Naturally Charles $\mathrm{v}$ banned this, but the order had to be repeated by his son in 1556. These abuses induced restrictions on who could issue passports. Both the Duke of Alba in 1572 and the Prince of Parma ten years later stipulated that only colonels could issue passports to soldiers. Similar measures were taken on the side of the rebels,

36 ROPB, IV, 459-460, Decree of 26 May 1543; ROPB, IV, 740-742, Decree from 1552 in French and in Dutch from 1555; Tweeden druck vanden eersten bouck der ordonnancien, 740-742. See also ROPB, IV, 16, for an ordinance from 1537 mentioning soldiers who needed a passport to enter a city.

37 AGA, Hof van Gelre en Zutphen, 1063, no. 1*; Hensken van Oerschot to the stadtholder of Guelders, 17 April 1544 (his passport dated 1 February 1544 is no. $1^{\star} \mathrm{a}$ ); AGA, Hof van Gelre en Zutphen, 4524, Testimony of the same Hensken in dossier 1544/1. For soldiers arrested for garden or crime, see AGA, Hof van Gelre en Zutphen, 4524, dossiers 1545/2 and 1547/1; AGA, Hof van Gelre en Zutphen, 4526, dossiers 1560/5, 1560/6, 1560/7, 1561/2, $1561 / 3,1562 / 1,1562 / 2,1562 / 3$, and $1563 / 4$.

38 AGA, Hof van Gelre en Zutphen, 642, no. 158, Court of Guelders to the stadtholder, 10 June 1552. The stadtholder had his suspicions: AGA, Hof van Gelre en Zutphen, 642, no. 161.

39 Swart, Krijgsvolk, 76.

40 Register van Holland en Westvriesland (1584), 660-662.

41 Rethaan Macaré, 'Dagverhaal 1554', 302; Cruickshank, Elizabeth's army, 165-166. 
with for instance the requirement that the signature of the muster commissioner or garrison commander was needed to validate a passport. ${ }^{42}$

In conclusion, it seems fair to say that the use of passports to distinguish lordless soldiers and runaways from legitimate, serving soldiers was a qualified success in the Netherlands. The authorities continued to use them, because as a tool to enforce norms and control it was effective up to a point. Dismissal without passport was considered a punishment, certainly by the late 1570 . For soldiers a passport could prove the bearer was honourable and loyal rather than lordless, a vagabond or a runaway 'schelm'. Surviving examples show that although passports were not standardised, the wording was always roughly the same: the bearer had served well, loyally, and honourably. ${ }^{43}$ A soldier caught without a passport in rebel territory could, by the 1580 s, be summarily executed. ${ }^{44}$ Whether soldiers in the Netherlands used their passports as a testimonial of skill and experience as was common in the Empire is unclear, though this was the case in one sense, since a passport was required when enlisting in a new unit.

Ideally the passport provided some security for both the bearer and people who dealt with him, particularly in the countryside. It showed the bearer to be a decent, honourable, and legitimate soldier. But, as mentioned, passports could be forged, and the burdens of war and bad previous experiences with soldiers could nullify any respect for passports, as a young rebel soldier in Western Flanders discovered in 1578: despite wielding a passport issued by his captain, he was killed by peasants in an argument over the provision of lodgings. ${ }^{45}$

\section{Local Officers}

Time and again the Habsburg decrees against lordless soldiers in the Netherlands mention the local officers (bailiffs, sheriffs, judges). These were the men charged with promulgating and implementing the decrees and thereby stopping the soldiers from harassing the rural population. The stadtholders, as representatives of the Habsburg rulers in the provinces, played a crucial role in admonishing the officers to do their work. Combating lordless soldiers was

42 Tweeden druck vanden eersten bouck der ordonnancien, 31, Decree of 1556; Van Loon, Gelders placaetboeck, I, 238, Decree of 16 March 1556, reissued on 30 April 1557; Van Loon, Gelders placaet-boeck, I, 590-594, Decree of 29 January 1572; Placcaet ende Ordonnantie, Decree of 22 February 1582; NA, Kamer der Beden van de Generaliteit, 12, Instructions for muster commissioners, 8 October 1578; NA, Paulus Buys, 78, Ordinance for Nieuwenaar and Villers, ca. 1585.

43 NA, Paulus Buys, 37 (arts. 19, 22), Ordinance of 1578 for the infantry; Bor, Oorsprongk, book XxIV, 189; Van Hasselt, Geldersche oudheden I, 423, Passport from 1523; AGA, Hof van Gelre en Zutphen 1063, no. $1^{\star}$ a, Passport from 1544; AGA, Hof van Gelre en Zutphen, 4530, Two passports from 1588 and 1591, dossier 1591/2; The correspondence of Prince William of Orange also contains passports for soldiers, for instance no. 1979 and no. 2008: http://resources.huygens.knaw.nl/wvo/(Accessed on 28 April 2020).

44 Register van Holland en Westvriesland (1580-1581), 534 (art. 19); NA, Paulus Buys, 78, Ordinance for Nieuwenaar and Villers, ca. 1585; Placcaet ende Ordonnantie, Parma's decree of 22 February 1582.

45 De Kempenare, Vlaemsche kronijk, 221-222. 
an integral part of their instructions and oath. ${ }^{46}$ Provincial courts of justice, like the Court of Guelders or the Council of Flanders, fulfilled the same role, and also made sure the officers received the decrees they were supposed to promulgate and implement. The provincial estates played no active role in this before the Revolt, as these were not permanent bodies. But when gathered they could and would remind their Habsburg lord and his representatives of a lord's duty to protect and defend his subjects, specifically mentioning the 'heerlose knechten'. The States of Holland did so in 1536, those of Friesland in 1545 and 1551, and those of Guelders in $1555 .{ }^{47}$ This was very much an echo of the near continual complaints and requests by subjects on this matter, usually directed at the stadtholders or the provincial courts of justice, such as the letter sent by the Oldebroek peasants cited at the beginning of this article.

In practice it seems that the officers were often found wanting. They could not or would not intervene when unemployed soldiers harassed the countryside. They obviously stood no chance against gatherings of hundreds or thousands of well-organised armed men. By the 1540 s such large gatherings were rare, yet still it appears that the officers failed to protect the rural population. In 1545 the stadhouder of Guelders noted as much and in 1556 Philip II threatened to strip any officer who failed to do his work of his office. ${ }^{8}$ One factor was that even apprehending a small group of soldiers required extra men on horseback or on foot, whom officers had to pay out of their own pocket. At least in Guelders in 1555 and Brabant in 1562 they complained about this and were then allowed compensation. ${ }^{49}$ The provincial administration offered the officers little concrete assistance, beyond reiterating what their duties were, ordering the decrees to be promulgated anew, or admonishing neighbouring officers to help each other. Thus, the peasants' plea for help in Oldebroek, which seems to have been drawn up by the local judge, was answered by a letter ordering him to capture the wrongdoers. Another letter was sent to the sheriff of the neighbouring city of Elburg, who was supposed to assist. ${ }^{50}$ Ineffective action by Guelders' officers

46 Schwartzenberg, Groot placaat en charter-boek van Vriesland, II, 806, Instruction for Frisian stadhouder, 1540; Schwartzenberg, Groot placaat en charter-boek van Vriesland, III, 111-112, Ordinance of Frisian stadhouder, 16 September 1546; ROPB, VIII, 86, Instruction for the stadholder of Guelders, 18 June 1560; ; Bondam, Verzameling van onuitgegeevene stukken, I, 92-93, Oath of the stadtholder of Guelders, 11 November 1576; Het tweede protest, 14, Oath of Guelders stadhouder, 11 June 1578.

47 Register Aert vander Goes, I, 515; Schwartzenberg, Groot placaat en charter-boek van Vriesland, III, 69, Estates of Friesland, 7 July 1545; Schwartzenberg, Groot placaat en charter-boek van Vriesland, III, 243, Estates of Friesland, June 1551; AGA, Hof van Gelre en Zupthen, 1553, fols. 44-48, Demands of States of Gelre, 12 July 1555 ; Van Loon, Gelders placaet-boeck I, 52, Court of Guelders, 3 February 1553; AGA, Hof van Gelre en Zutphen, 986, no. 1698, Court of Guelders to the judge of Arnhem and the Veluwezoom, 29 April 1557; Gunn, Grummitt, and Cools, War, State and Society, 245-246.

48 AGA, Hof van Gelre en Zutphen, 642, no. 15, Stadhouder of Guelders to Court of Guelders, 3 May 1545; Van Loon, Gelders placaet-boeck, I, 192-194, Decree 8 May 1556. Also in 1559: see Van Loon, Gelders placaet-boeck, I, 265-269; AGA, Hof van Gelre en Zutphen, 986, no. 1698, Court of Guelders to the judge of Arnhem and the Veluwezoom, 29 April 1557.

49 Van Loon, Gelders placaet-boeck, I, 185-186, Ordinance of 11 October 1555. For a preference in 1556 for infantry over horsemen in chasing lordless soldiers, see Van Loon, Gelders placaet-boeck, I, 191-192; Placcaerten, ordonnantien ende edicten van de hertoghen van Brabandt, 354, Decree of 24 March 1562.

50 AGA, Hof van Gelre en Zutphen, 986, no. 1407, Request of the peasants, dated 19 February 1555; AGA, Hof van Gelre en Zutphen, 986, no. 1411, Court of Guelders to the judge of Oldebroek, 25 February 1555; AGA, Hof van Gelre en Zutphen, 986, no. 1412, Court of Guelders to the sheriff of Elburg. 
against lordless soldiers after 1555 did lead to the introduction, in 1559, of a new officer called schutmeester, who was appointed by the stadtholder and could presumably patrol the entire province with his men. A mere five years later the office was abolished. ${ }^{51}$ Other provinces - for instance Groningen in 1556 and Overijssel in 1613 - also raised such ad hoc mobile units..$^{52}$

The letter to the sheriff of Elburg also hints at another problem, namely that willingness to help each other was sometimes lacking. In 1545 , for instance, the sheriff of the Veluwe was overwhelmed, but he received no assistance from neighbouring colleagues or the nearby garrison. There are even indications that officers would simply persuade or pay the unemployed soldiers to move on and leave their jurisdiction, thus making them someone else's problem. This is recorded for Brabant in $1562 .{ }^{53}$ Furthermore, each of the provinces jealously guarded its own rights and privileges and did not allow officers to operate across provincial borders. In 1468 Duke Charles the Bold of Burgundy had attempted to counter this problem by making the office of provost marshal permanent with jurisdiction in all his territories. This office may have become defunct and then reinstituted by Charles $\mathrm{v}$, who also created provincial provost marshals. The latter became permanent officers in the southern provinces. Problems with soldiers in war and peace were very much the reason for their institution..$^{54}$

Yet crossing provincial boundaries remained a problem. This became apparent in 1564, when the stadtholder and Court of Guelders approached the stadtholder of Overijssel to conclude a treaty that would allow officers to pursue wrongdoers - including 'heerlose knechten' - across the provincial border, apprehend them, and then hand them over to the local authorities. The stadtholder of Overijssel, after consulting his officers, agreed, but what happened next is unclear..$^{55}$ During wartime in 1581 , the rebellious estates of Holland, Utrecht, and the Veluwe together appointed a sheriff with jurisdiction in all their lands. With eleven horsemen and twenty-five men on foot, all heavily-armed and well-paid, a clerk and an executioner, he was to go on patrol at least every fourteen days and run down vagabonds, 'heerlose soldaaten', and other criminals. ${ }^{56}$ This sheriff is never mentioned again, however. In 1589 the States-General authorised officers, peasants, and soldiers to cross provincial borders to capture enemy soldiers in adjacent localities. ${ }^{57}$ Whether this

51 Kronijk van Arnhem, 109, 147; AGA, Hof van Gelre en Zutphen, 655, no. 1365, Court of Guelders to Council of Finances, 5 January 1560. The reply is in AGA, Hof van Gelre en Zutphen, 655, no. 1368. See also AGA, Hof van Gelre en Zutphen 1055, no. 4148, Sheriff of Geldern to Court of Guelders, 18 September 1570, who mentions the 'schutmeester' again.

52 Alting, Diarium, 53. For Overijssel, see Resolutiën Staten-Generaal 1610-1670, II, 130, 15 October 1613.

53 AGA, Hof van Gelre en Zutphen, 642, no. 15, Court of Guelders to stadtholder, 3 May 1545; Placcaerten, ordonnantien ende edicten van de hertoghen van Brabandt, 356, 358, Decree of 24 March 1562.

54 Schnerb, 'L’honneur de la maréchaussée', 157-175; ARAB, Audience 802, fols. 17-18, 19-20, 62-63v, 67-69v, and 110-111, Instructions for the prévôts des maréchaux of Lille, Douai, and Orchies (1565), Hainaut (1565 and undated), Namur (1575), Luxembourg, and Chiny (1596); Robaulx de Soumoy, Étude, 26, 29-30; Devillers, Inventaire analytique d'Hainaut, I, 169, 171-172, 174, 176, 180, 182, 199, 229.

55 AGA, Hof van Gelre en Zutphen, 4411, Instruction for Johan Wurdt, 11 March 1564, and the response of Arenberg, 16 March 1564.

56 Register van Holland en Westvriesland (1580-1581), 531-537, Instruction for Willem de Ridder van Orvenensteyn as sheriff, 28 April 1581. The 'heerlose soldaaten' are mentioned in article 10.

57 Bor, Oorspongk, book xxvi, 421-423, Decree of 27 April 1589. 
was also permitted in other cases is unclear. In the United Provinces crossing provincial borders remained a sensitive issue only allowed in specific cases. The 1579 Union of Utrecht, which functioned as their 'constitution', was primarily a defensive alliance against common, external enemies. Only occasionally, entirely ad hoc, did the States-General deal with problems caused by disbanded soldiers and vagabonds. ${ }^{58}$

It is clear that not everyone shared the Habsburg authorities' perception of unemployed soldiers as a threat or their views on the best manner of dealing with them. Hoogstraten as stadtholder of Guelders might in 1554 exclaim he wanted to 'cleanse the land and exterminate those vagabonds', but violent repression was often neither feasible nor sensible. ${ }^{59}$ Both officers and peasants could get themselves killed this way. Placating the soldiers and trying to move them on might appear the better option, if only because it was the lesser of two evils. In 1562 the Habsburg authorities accused some officers in Brabant of being in cahoots with marauding bands. ${ }^{60}$ Peasants seem to have been aware that garden had been outlawed, but when confronted by armed and potentially violent soldiers, providing them with food and shelter in the hope they would then move on probably seemed smarter. ${ }^{61}$ Even the Court of Guelders let off the soldiers interrogated for garden in 1545, 1547, and 1560-1563 with a warning and the order to leave the province, at least when it appeared they had used no force or threats. Only those suspected of other matters as well were held in custody. One unemployed soldier was suspected of involvement in theft from a church, another of calling allegedly drunk clergymen 'god eaters', and a third was found to possess an incantation. ${ }^{62}$

Unemployed soldiers might even have their uses, for instance as a source of cheap, stolen merchandise. In 1562 the second-hand clothes dealers were singled out for this by the government, but other stolen wares seem to have had no problem in finding new owners either. And as professionals skilled in the use of arms and violence, unemployed soldiers could be handy in a fight. A man involved in a feud with members of the noble Raesfelt family in 1555 over an inheritance in Guelders engaged some 'kriegslueden', who had been 'gairden', to carry out the threat of burning and robbing. Feuding merchants in Antwerp in 1561 also hired unemployed soldiers as muscle. ${ }^{63}$

58 Resolutiën Staten-Generaal 1576-1609, X, 21-22, 12 May 1598; Resolutiën Staten-Generaal 1576-1609, XIII, 307, 19 September 1605. See also the resolutions of 15 December 1629 (article 7), 18 December 1629 (article 24), and 19 December 1629 (article 15), in Nijenhuis et al. (eds.), Besluiten Staten-Generaal 1626-163o http://resources.huygens. knaw.nl/besluitenstatengeneraal1576-1630/BesluitenStaten-generaal1626-1651 (Accessed on 30 April 2020).

59 AGA, Hof van Gelre en Zutphen, 642, no. 207, Hoogstraten to Court of Guelders, 26 March 1554: 'affin de nectoyer le pays et exterminer lesd vagabondes'.

60 Placcaerten, ordonnantien ende edicten van de hertoghen van Brabandt, 356, 358, Decree of 24 March 1562.

61 Ruff, Violence, 227-228. See for instance, AGA, Hof van Gelre en Zutphen, 4526, dossier 1563/3.

62 For soldiers arrested for garden or crime, see AGA, Hof van Gelre en Zutphen, 4524, dossiers $1545 / 2$ and 1547/1; AGA, Hof van Gelre en Zutphen, 4526, dossiers 1560/5, 1560/6, 1560/7, 1561/2, 1561/3, 1562/1, 1562/2, $1562 / 3$, and $1563 / 4$. More specifically, calling clergymen 'gotten wreters' in dossier $1560 / 6$, and theft from a church and the incantation in dossier $1545 / 2$.

63 Placcaerten, ordonnantien ende edicten van de hertoghen van Brabandt, 356, Decree 24 March 1562; AGA, Hof van Gelre en Zutphen, 4525, Johan Dresmans' feud with Arend, Ludger, and Johan van Raesfelt in dossier 1555/3. Dresmans is dubbed 'entsagter viant' of the Raesfelts. For 'veede' in Antwerp, see RopB, VIII, 284-286, Decree 18 November 1561; Ruff, Violence, 219. 
Local officers throughout the Empire faced the same problems with unemployed soldiers and were generally as ineffective as their counterparts in the Netherlands when it came to dealing with them. They too were accused of not doing their work when it came to the lordless soldiers. ${ }^{64}$ The very large gatherings seem to have persisted somewhat longer in the Empire than in the Netherlands. Perhaps their disappearance in the Netherlands should be tied to the establishment and consolidation of Habsburg rule of which the incorporation of Guelders in 1543 was the final act.

For the upper echelons of government, the provision of security, of which combating the lordless soldiers was a vital part, presented an opportunity to both improve their image and strengthen their hold over their subjects. In the Empire, counteracting the Gartknechte, as part of maintaining the Landfrieden, was delegated to the territories. Occasionally territories would cooperate and field their own military forces against large gatherings of Gartknechte. In 1546 for instance, Hamburg, Lübeck, and Lüneburg teamed up with the Danish king to tackle a group of four thousand. Coordination of the Landfrieden, and thus controlling the lordless soldiers, often lay with regional organisations in the form of leagues, of which the Swabian League founded in 1488 is the best known and became the model for others. In 1555 upholding the Landfrieden was turned over to the Imperial Circles. ${ }^{65}$ And although the Empire itself remained relatively peaceful post 1555 , large numbers of German soldiers served abroad, notably in the French and Dutch civil wars. Lordless soldiers therefore remained a problem.

But the Imperial system of providing security on the whole supplied local officers with no more assistance than their Netherlandish counterparts received from their own lords. That the decrees against garden and lordless soldiers were frequently republished in both the Netherlands and the Empire makes clear they had limited effect. Occasionally additional mobile units (Streifrotten) were created to fight Gartknechte, sometimes even in cooperation between territories. Cologne, Münster, and Cleves in 1538 together fielded a unit of seventy-five horsemen that could be augmented to 550. These units compare well with those in the Netherlands mentioned earlier. The Streifrotten, which ironically contained many former Gartknechte, made little difference either. The sheer size of the problem, and the size and organisation of bands of lordless soldiers, was one reason for the lack of success. More important was that warring German rulers were willing to 'cooperate' with the bands, support and finance them, and use them for their own purposes. ${ }^{66} \mathrm{As}$ in the Netherlands, lordless soldiers in the Empire could also readily escape across borders to other jurisdictions, in spite of some efforts at the level of the Imperial Circles to allow pursuit and support across territorial borders. ${ }^{67}$

64 Burschel, Söldner, 313-314.

65 Carl, 'Landfriedensbrecher', 274-275; Lanzinner, 'Ein Sicherheitssystem'; Burschel, Söldner, 292-293; Carl, Der Schwäbische Bund; Weber, 'Landfriedenspolitik im Schwäbischen Kreis'.

66 Lanzinner, 'Ein Sicherheitssystem', 109; Burschel, Söldner, 296, 310, 315-316; Carl, 'Landfriedensbrecher', 287; Huntebrinker, “'Gartknecht” und "Passport”, 14, 17; Reusch, “"Bedrohliche Mobilität”, 223-225; Weber, 'Landfriedenspolitik im Schwäbischen Kreis', 191-193, 196, 198-199.

67 Reusch, “"Bedrohliche Mobilität”', 223-224; Weber, 'Landfriedenspolitik im Schwäbischen Kreis', $192-193$. 


\section{Rural Self-Defence}

Another feature that constantly appears in decrees against lordless soldiers, is that officers who encountered resistance or were outnumbered could mobilise the rural population for assistance in apprehending the miscreants. To summon them the officers could ring the bells. The basic principle behind this had existed since the early Middle Ages, namely that every free man could be called upon to bear arms. They could be employed offensively against their lord's enemies, and defensively to defend their own land. Emperor Charles v, for instance, asserted that all his subjects had a duty to defend their homes and the authority of their lord. ${ }^{68}$ The defensive role was probably the most fundamental and original, and provided the context for the use of the men of the rural levy against unemployed soldiers and the like. Ringing the bells as a sign for the levy to gather was a tradition going back centuries. ${ }^{69}$

The subject of these levies in the Netherlands of the sixteenth century needs more research, notably on the role the prince and his representatives therein. What is clear is that this communal army had a territorial organisation, and that local sheriffs, bailiffs, and judges were responsible for overseeing the mobilisation, conducting musters, and leading the levy in action. The musters, initiated by the sovereign or his representatives, notably the stadtholders, were intended to see how many men were available and whether they kept the arms and equipment they had been ordered to keep. Ideally, musters were to be conducted regularly, but apparently they only happened in the face of an imminent threat. $^{70}$

Friesland has been well served by a recent study on its communal army in the first half of the sixteenth century. It seems that in practice only one man per household served, which may have been the case elsewhere too. Since each man had to equip himself, armament was determined by wealth. Armour was only for the wealthy. Most were only armed with a sword and a pole weapon, mostly a pike; in rural areas only twelve percent possessed a firearm. Approximately twenty to thirty percent of men were too ill or poor to serve. A number of the latter received arms from communal stores in some areas. In total, Friesland mustered nearly fourteen thousand men. For actual service a selection called the 'third man' could be called out, perhaps thirty-eight hundred men of whom around a third possessed armour; obviously the most suitable and best-equipped men were selected

68 Gunn, Grummitt, Cools, War, State, and Society, 243; Mol, De Friese volkslegers, 14, 18. Ringing the bells is mentioned in ROPB, II, 130-131, 230 (in 1522); ROPB, III, 541-542 (in 1536); ROPB, IV, 29-30, 462-463 (in 1537 and 1543); RОРв, V, 4, 92-93 (in 1543 and 1544); ROPB, VI, 353 (in 1553); Van Loon, Gelders placaet-boeck I, 179180, 238, 700-706; Vande Water, Groot placaatboek van Utrecht, I, 694-695, 697-702; Bor, Oorsprongk, book IX, 714; Adriaenssen, Staatsvormend geweld, 43-46; Nicholson, Medieval warfare, 46.

69 Van Hasselt, Geldersche Oudheden, I, 348-349, mentions Guelders in 1338, 1417, and 1427.

70 Mol, De Friese volkslegers, 13-15, 59-61, 64, 66, 70; ROPB, IV, 562-563, Imperial decree ordering musters in Flanders, 9 June 1543; Van Loon, Gelders placaet-boeck, I, 124, Decree of the stadtholder of Guelders ordering musters, 29 December 1551; Schwartzenberg, Groot placaat en charter-boek van Vriesland, II, 499, Decree for musters in Friesland, 31 May 1525; AGA, Hof van Gelre en Zutphen, 1045, no. 552, stadtholder to the Duchess-Widow of Guelders, 4 June 1547; Adriaenssen, Staatsvormend geweld, 43, 401-402. 
here. This 'third man' is also mentioned for rural Groningen. ${ }^{71}$ Information on arms and equipment of the communal army in Holland suggests no great difference from those in Friesland. Surviving muster rolls drawn up in Guelders early in 1552, however, mention but little armour. Two localities specifically mention that their armour, even arms, were lost or taken away in the last war. The rolls also list men serving with horse and waggon and others bringing merely a horse. The latter were evidently supposed to serve on horseback, but the stadtholder had already remarked in 1547 that many simply brought 'a naked horse without any weapons' and thus were of little or no use. He preferred to have them serve on foot instead. ${ }^{72}$

Although it is clear that the use of the rural levy in warfare was declining, particularly offensively, it still took some part in military operations in the Netherlands into the 1520 . This is documented for Friesland and Groningen. Guelders and Habsburg Brabant used the rural levy as well, with Den Bosch employing it to attack Guelders and burn the Bommelerwaard in $1512 .^{73}$ Its use for defensive duties, such as providing security for home and land, remained in place the longest, with the Habsburg authorities ordering the levy in threatened provinces to be ready to confront a possible invasion. This happened several times in Flanders, Walloon Flanders, and Hainaut in the 1480 s, 1520 s, and 1540 s. $^{74}$ Late $^{2}$ in 1551, fearing a concerted effort between the French king and his German allies, the situation seemed particularly threatening, and so the government ordered musters in (parts of) Guelders, Friesland, Holland, and Flanders for the 'defence' of the Netherlands. ${ }^{75}$ These took part in the early months of 1552 .

Mobilising the rural levy remained very much an option. In September 1576, in response to widespread mutiny in the royal army, the Council of State, standing in for the sovereign, issued a decree calling all subjects to arms against the mutineers and ordering the officers to muster them. In one recorded case, three thousand Flemish peasants led by a bailiff chased Spanish mutineers. ${ }^{76}$ Article eight of the Union of Utrecht, concluded between the rebellious provinces in 1579, should also be seen in this tradition. It ordered the musters within a month of all men between the ages of eighteen and sixty, so that they might serve the 'protection and security of these united lands'. ${ }^{77}$ Utrecht was the only one of the

71 Mol, De Friese volkslegers, 55, 72, 76-77, 78-80, 82, 85, 87, 95; Benninge, Croniken der Vrescher Landen, 444, 466. See also Adriaenssen, Staatsvormend geweld, 43, and for Holland, Bronnen dagvaarten Holland, vi, 76, 401, 509-510.

$72 \mathrm{Mol}$, De Friese volkslegers, 100; AGA, Hof van Gelre en Zutphen, 2018, 'Monstercedulen' from Guelders, 1552. The rolls from Grefrath and Krieckenbeck mention the loss of weapons and/or armour, and 'een naeckt peert sonder eenich geweer': AGA, Hof van Gelre en Zutphen, 1045, no. 577, stadtholder to the sheriff of Geldern, 10 July 1547 .

73 Mol, De Friese volkslegers, 124-125, 159-165; Benninge, Croniken der Vrescher Landen, 156-157, 207, 444, 466; Van Os, Kroniek van Peter van Os, 308, 311, 322.

74 Gunn, Grummitt, Cools, War, State, and Society, 57, 243.

75 Diegerick, Inventaire ville d'Ypres, vII, 282-283, Governess-general to States of Flanders, 6 January 1552; Van Loon, Gelders placaet-boeck, I, 124, Decree of stadtholder of Guelders, 29 December 1551; Mol, De Friese volkslegers, 60-61.

76 Bor, Oorsprongk, book Ix, 714-715; Adriaenssen, Staatsvormend geweld, 402.

77 Cited in Groenveld, Unie - Bestand - Vrede, 64: 'die [...] bescherminge ende verseeckertheyt van dese gheunieerde landen'; Paulus, Verklaring der Unie van Utrecht, II, 137-141. 
provinces which actually carried out such a muster, the other provinces never did. The levy continued to play the same role it had done before the Union. Standing watch in their own locality, for instance, is widely documented after 1572 . Occasionally the levy received orders to keep watch along a longer stretch of territory, like in Northern Holland in 1575. In Guelders the rural levy keeping watch along the river IJssel is mentioned in 1567,1581 , 1584 , and 1598 . This was especially urgent in winter when it froze over. It is also clear that local officers continued to be ordered to conduct musters and keep rolls of the available men and their equipment. ${ }^{78}$

While tackling the problem of lordless soldiers was an obvious use of the rural levy, it was not very effective in this role. One problem was that gathering the men took time. By the time they were ready to tackle the group in question, the soldiers, highly mobile and not keen on confrontation, might be long gone. Hence, as early as 1494 the States of Brabant proposed that three to four thousand men in each of the four Quarters of the province should be ready to intervene at a moment's notice. The officer leading them would have to bring money or supplies for two days. Although their Habsburg lord Philip the Fair agreed, it is unclear whether this measure was carried out. ${ }^{79}$ Another problem was that the levy could not gather on its own initiative: the order needed to come from their local officer. Only one decree from 1555 mentions that the peasants could ring the bells and act of their own accord. ${ }^{80}$ It is typical that villages in the Langstraat region in 1581 had to petition the rebellious States of Holland for permission to defend themselves against assailants such as vagabonds, which was granted. In 1589 the States-General determined that peasants were allowed to ring the bells without asking for permission when confronted with enemy troops, but the placard makes it very clear that this was an exception to the rule. ${ }^{81}$

The rural levy was also no match for soldiers in an open fight, especially when the numbers were roughly even. The chronicler Sicke Benninge cynically remarked in the context of a fight in 1516 that when the rural levy was attacked it generally fled. The three thousand Flemish peasants mentioned earlier were soundly beaten by the outnumbered Spanish mutineers in $1576 .{ }^{82}$ In 1580 there was a full scale 'peasant war' in Overijssel and Guelders, probably because disgruntled officers wanting to remain loyal to the Habsburgs mobilised

78 Bor, Oorsprongk, book xviII, 384; Bor, Oorsprongk, book viII, 621-623, Ordinance on the watch in northern Holland, 9 May 1575. For southern Holland in 1572-1574, see Register van Holland en Westvriesland (15651574), 618-620, 821-822, 899. For Flanders, see De Kempenare, Vlaemsche kronijk, 191, 225-226, 271, 278-279; Chronijcke van Ghendt, 393. On the watch along the River IJssel, see AGA, Hof van Gelre en Zutphen, 643 , no. 486, stadtholder to Court of Guelders, 5 May 1567; AGA, Hof van Gelre en Zutphen, 995, no. 4835, Sheriff of the Veluwe to Court of Guelders, 2 September 1581; AGA, Hof van Gelre en Zutphen, 997, no. 5021, Court of Guelders to sheriffs of Ede, Putten, Nijkerk, and Apeldoorn, 22 January 1584; AGA, Hof van Gelre en Zutphen, 1007 , no. 8375, Court of Guelders to sheriffs of the Veluwezoom and Ede, 5 January 1598, as well as no. 8379 dated 11 January 1598.

79 Van Os, Kroniek van Peter van Os, 271-272. For similar, later proposals, see Adriaenssen, Staatsvormend geweld, 64 .

8o Van Loon, Gelders placaet-boeck, I, 179-180, Decree of 15 March 1555.

81 Register van Holland ende Westvriesland (1580-1581), 801, Resolution of 14 August 1581; Bor, Oorsprongk, book XxVI, 421-423, Placard of the States-General, 27 April 1589.

82 Benninge, Croniken der Vrescher Landen, 396; Bor, Oorsprongk, book IX, 715; Mol, De Friese volkslegers, 130-131, 163-164; Swart, Krijgsvolk, 152-153; Adriaenssen, Staatsvormend geweld, 407-411. 
the levy. These too were quickly beaten and dispersed by rebel troops. ${ }^{83}$ The professional soldiers were better armed and equipped, more skilled in using their weapons, and had the kind of cohesion a group of peasants that only assembled in emergencies simply did not possess. In Friesland some attempts were made at what might be called 'professionalization' of the levy, or at least of the 'third man'. In ordinances from 1528 and 1535 the Habsburg stadtholder ordered the organisation of the 'third man' in companies like those of the professionals. These should be ready to assemble at short notice. In the latter year the appointment of professional captains and cadre was also foreseen. ${ }^{84}$ This might actually offer employment for some of the unemployed soldiers the companies could be used against. However, to what extent the ordinance was carried out seems to be unclear.

In spite of all its defects self-defence by the rural population continued to play a role in both peace and war, and often proved effective against small groups of soldiers if the levy responded in time. In one instance in 1595, two English soldiers on the road from Arnhem to Wageningen got in an altercation with a peasant woman while attempting to buy beer from her. When they departed they were soon set upon by six or seven peasants with pole weapons, stabbed, beaten, and then captured. In 1597 the Court of Guelders ordered various sheriffs to have the peasants chase soldiers and vagabonds. ${ }^{85}$ Naturally, when the States of the Quarter of Zutphen took renewed measures against 'lordless soldiers and vagabonds' following the Truce of 1609 , the assistance of the peasants was integral to their success. ${ }^{86}$ It should be noted however, that this depended on the presence of a rural population. In many frontline areas in the 1580 s the war had caused severe depopulation, as the peasants fled to the safety of a city. The 1590 s saw improvement in some areas, if only because poverty forced peasants to return to their land, but Flanders and Northern Brabant for instance remained severely affected. ${ }^{87}$

Although the authorities' discourse designated certain types of soldiers as a threat 'lordless' being one such group, as well as 'mutineers', 'rebels', or 'enemies' - for the rural population the distinction was probably irrelevant, because in their eyes all soldiers were a burden and a threat. In August 1576 a unit of soldiers in Guelders complained to the stadtholder about harassment by peasants. They claimed to have done nothing wrong and an angry stadtholder designated the peasants' actions as rebellion which deserved violent repression. The Court of Guelders advised against this, and avoided the term 'rebellion',

83 Van Veen, 'De boerenopstand in 1580', 61-62, 63; Bor, Oorsprongk, book xIV, 162, 166, 170, $177-178$.

$84 \mathrm{Mol}$, De Friese volkslegers, 54-55, 58-59, 135.

85 The two English soldiers are mentioned in AGA, Hof van Gelre en Zutphen, 4531, dossier 1595/2; AGA, Hof van Gelre en Zutphen, 1006, nos. 8119, 8254, and 8367, Letters of the Court of Guelders, 12 February, 4 August, and 19 December 1597.

86 AGA, Staten van het Kwartier van Zutphen en hun Gedeputeerden, 1367, Commission of 4 May 1609. 87 Adriaenssen, Staatsvormend geweld, 270-272, 276-277, 412-413; Swart, Krijgsvolk, 151-152; Chronijcke van Ghendt, 302-303, 305, 315, 338-339, 390; De Kempenare, Vlaemsche kronijk, 234-236, 246-248, 252, 255, 257, 259, 298, 321, 326; Piceu, Over vrybuiters en quaetdoenders; AGA, Hof van Gelre en Zutphen, 1000, no. 5871, Wageningen to Court of Guelders, 6 April 1589; AGA, Hof van Gelre en Zutphen, 1003, no. 6871, Sheriff of Ede to Court of Guelders, 2 April 1592; AGA, Hof van Gelre en Zutphen, 998, no. 5372, Sheriffs of Ermelo and Putten to Court of Guelders, 20 April 1587. 
but still wanted to prosecute the peasants. ${ }^{88}$ During the wartime years after 1572 peasants were occasionally arrested for murdering soldiers. ${ }^{89}$

In the Empire levies of subjects were also an integral part of the repertoire available for maintaining the peace and thus in tackling lordless soldiers. The so-called Nacheile by subjects was therefore as a matter of course incorporated in the Reichsexekutionsordnung of 1555 . On the whole they were not effective against soldiers, except when dealing with small numbers, as were those in the Netherlands. Around 1600, a substantial number of German rulers attempted to organise a more permanent militia of subjects as an alternative to expensive professional soldiers. For these Landesdefensionen the rulers were keen to engage men with previous military experience. In this way they provided an alternative to garden for unemployed soldiers, with passports being demanded as proof of experience. The cadre was also composed of former professional soldiers, offering a parallel with the attempt at 'professionalization' of the 'third man' earlier in Friesland. Such attempts have not been recorded elsewhere in the Netherlands. The Landesdefensionen had no chance in an open fight with professional soldiers either, but it seems they had some success in keeping away Gartknechte from their own territory..$^{\circ}$

\section{Conclusion}

The discourse on unemployed soldiers as a security threat did not completely disappear until after the end of the Eighty Years' War and Thirty Years' War in 1648. As late as 1653 the Nassau stadtholder of Friesland published a decree against discharged soldiers who bothered the population. ${ }^{91}$ The discourse disappeared partly because they gradually merged with other groups into the 'lordless rabble', and partly because princes created standing armies, just as there was a growing demand for soldiers after $1650 .{ }^{92}$ It is easy to see the developing sixteenth-century discourse on unemployed soldiers and resulting measures as part of the state-building process. Discourses on threats such as soldiers, or rather their securitization, helped rulers in strengthening their hold over their subjects. But in neither the sixteenth-century Netherlands nor the Empire was it that straightforward. Rulers did not have a monopoly on violence and in practice needed to cooperate with many agents. They depended entirely on local officers (sheriffs, bailiffs, judges) and the rural population to carry out their measures. All had their own agenda and realities. Rather than arrest the lordless soldiers or use violence against them, as the authorities

88 AGA, Hof van Gelre en Zutphen, 646, no. 1165, stadtholder to the Court of Guelders, 26 August 1576. The reply is dated 31 August 1576: AGA, Hof van Gelre en Zutphen, 646, no.1167.

89 AGA, Hof van Gelre en Zutphen, 997, no. 5073, Commission by Adolf van Nieuwenaar, October 1584; AGA, Hof van Gelre en Zutphen, 997, 5153, Sheriff of the Veluwe to Gerlich van der Capelle in Utrecht, 12 August 1585.

90 Carl, 'Landfriedensbrecher', 284-286; Weber, 'Landfriedenspolitik im Schwäbischen Kreis', 192-193, 196, 197, 203-204; Reusch, "'Bedrohliche Mobilität”, 223-224; Burschel, Söldner, 79-80. See for England: Boynton, The Elizabethan militia, 60, 99-100, 106, 118, 246-247; Hammer, Elizabeth's wars, 102-104, 141-142.

91 Leeuwarden, Tresoar, Stadsbestuur Stavoren, 235, Decree of 1653.

92 Carl, 'Landfriedensbrecher', 286-287; Reusch, “"Bedrohliche Mobilität”', 224-226; Burschel, Söldner, 113115, 286; Egmond, Underworlds, 49-50. 
decreed, officers and peasants often thought it more sensible to placate them or buy them off. The soldiers then became somebody else's problem.

The claims of the sovereign to provide security in the form of protection, in this case against unemployed soldiers, were found wanting. None of the measures proposed against lordless soldiers proved unequivocally effective. The passports for legitimate soldiers became standard, but could be forged or bought. They had some effect in enforcing norms and control but their success depended on soldiers finding the passports useful for themselves, particularly in the Empire, where they were used as testimonials of experience. The introduction of mobile units (the so-called Streifrotten in German) is documented in both the Empire and the Netherlands. The local levy could be summoned to assist if need be. Both could be useful against smaller groups of soldiers, but in an even fight generally were no match for them. Furthermore, the soldiers could often escape to another jurisdiction to evade capture. It was this combination of mobility and ability when it came to violence in particular that made them such a security threat. Attempts at 'professionalisation' of the levy did not substantially alter the situation. The near incessant stream of decrees by rulers on the one hand, and the even more abundant complaints and pleas for help by subjects on the other, testify to the persistence of the problem of unemployed soldiers.

There is a peculiar paradox present in this security policy, especially in the Empire, as rulers required the very Gartknechte who were causing problems for Streifrotten and Landesdefensionen to be used to confront other unemployed soldiers. Furthermore, rulers and their subjects may have perceived unemployed soldiers to be a growing problem in the sixteenth century, but this was a consequence of the increasing scale of warfare, for which rulers such as the Habsburgs were themselves responsible. In the Netherlands the problem was further aggravated by the ban on soldiers serving abroad without permission. This obliged unemployed soldiers to stay home until the government needed them, but at the same time produced the context within which many saw no option but garden.

In practice both the Netherlands and the Empire developed a collective security regime, which depended on cooperation to maintain the common peace or Landfrieden against threats like unemployed soldiers. There is, however, no contradiction here with rulers extending their grip on their territories. But there is a clear difference between the Netherlands and the Empire. Within the latter, an appeal to the Landfrieden allowed the implementation of supra-territorial, regional security policies, from 1555 in the Imperial Circles. For the Netherlandish provinces on the other hand, such policies for combating the 'heerloese knechten' remained elusive, even under the 1579 Union of Utrecht. Only occasionally, and then entirely ad hoc, did the States-General of the United Provinces deal with problems caused by disbanded soldiers.

\section{Bibliography}

Archival and Manuscript Sources

Arnhem, Gelders Archief (AGA), Hof van Gelre en Zutphen, inv. nos. 110, 642, 646, 658, 983, 985, 986, 997, 998, 1000, 1003, 1049, 1063, 4411, 4524, 4526. 
AGA, Staten van het Kwartier van Zutphen en hun Gedeputeerden, inv. no.1367.

Brussels, Algemeen Rijksarchief (ARAB), Duitse Staatsecretarie, inv. no. 112.

Brussels, Rijksarchief Vorst (RAV), Archief van de Drossaard van Brabant en Provoost van het Hof, inv. no. 253.

Courtrai, Rijksarchief (RAK), Archieffonds D’Ennetières, inv. nos. 660-662.

Groningen, Groninger Archieven (GA), Inventaris van het archief van het Stadsbestuur van Groningen 1594-1815.

Leeuwarden, Tresoar, Stadsbestuur Stavoren, inv. no. 235.

The Hague, National Archives (NA), Hof van Holland, inv. nos. 3547, 3551, 3546, 5654.

NA, Kamer der Beden van de Generaliteit, inv. no. 12.

NA, Archief van mr. Paulus Buys, 1572-1587, inv. no. 78.

Zutphen, Regionaal Archief Zutphen (RAZ), Archiefnummer 1, Resolutions of the magistrate, 1573-1620.

\section{Printed Sources}

Adriaenssens, Leo, Staatsvormend geweld. Overleven aan de frontlinies in de Meijerij van Den Bosch, 15721629 (Tilburg 2007).

Alting, Egbert, Diarium van Egbert Alting. W.J. Formsma and R. van Royen (eds.) (The Hague 1964).

Asche, Matthias, 'Bellizität, Staat und Migration im Alten Reich', in Jochen Oltmer (ed.), Handbuch Staat und Migration in Deutschland seit dem 17. Jahrhundert (Berlin 2015) 87-116.

Aurelius, Cornelius, Die cronycke van Hollandt Zeelandt ende Vrieslant beghinnende van Adams tyden, tot die geboerte ons Heren Jhesu, voortgaende tot den jare MCCCCC ende XVII (Leiden: Jan Seversz, 1517).

Baumann, Reinhard, Landsknechte. Ihre Geschichte und Kultur vom späten Mittelalter bis zum Dreißigjährigen Krieg (Munich 1994).

Baumann, Reinhard, 'Feldzugs- und Gartmigration von Kriegsleuten im 16. Jahrhundert', in Reinhard Baumann and Rolf Kießling (eds.), Mobilität und Migration in der Region (Konstanz 2013) 65-84.

Behr, Hans-Joachim, 'Garden und Vergardung. Das Problem der herrenlosen Landsknechte im 16. Jahrhundert', Westfälische Zeitschrift 145 (1995) 41-72.

Beier, A.L., Masterless men. The vagrancy problem in England, 1560-1640 (London 1985).

Benninge, Sicke, Croniken der Vrescher Landen mijtten Zoeven Seelanden ende der stadt Groningen, F.A.H. van den Hombergh, E.O. van der Werff, and A.J. Rinzema (eds.) (The Hague 2012).

Bondam, Pieter, Verzameling van onuitgegeevene stukken tot opheldering der vaderlandsche historie, 5 vols. (Utrecht: Bartholome Wild, 1779).

Booth, Ken, and Nicholas J. Wheeler, 'Uncertainty', in Paul D. Williams (ed.), Security studies. An introduction (Abingdon 2008) 133-150.

Bor, Pieter Christiaensz, Oorsprongk, begin, en vervolgh der Nederlandsche oorlogen, beroerten en borgerlyke oneenigheden, 4 vols. (Amsterdam: Widow Johan van Someren, Abraham Wolfgangh, Hendrick en Dirck Boom, 4th ed. 1679-1684).

Boynton, Lindsay, The Elizabethan militia, 1558-1638 (London 1967).

Bronnen voor de geschiedenis der dagvaarten van de Staten en steden van Holland vóór 1544. W. Prevenier et al. (eds.), 6 vols. (The Hague 1991-2006).

Burschel, Peter, Söldner im Nordwestdeutschland des 16. und 17. Jahrhundert (Göttingen 1994).

Buzan, Barry and Lene Hansen, The Evolution of International Security Studies (Cambridge 2009).

Carl, Horst, Der Schwäbische Bund, 1488-1534. Landfrieden und Genossenschaft im Übergang vom Spätmittelalter zur Reformation (Leinfelden-Echterdingen 2000).

Carl, Horst, 'Landfrieden als Konzept und Realität kollektiver Sicherheit im Heiligen Römischen Reich', in Gisela Naegle (ed.), Frieden schaffen und sich verteidigen im Spätmittelalter/Faire la paix et se défendre à la fin du Moyen Âge (Munich 2012) 121-138.

Carl, Horst, 'Einleitung in die Sektion. Sicherheit vor Gewalt - Sicherheit durch Gewalt', in Christoph Kampmann and Ulrich Niggemann (eds.), Sicherheit in der Frühen Neuzeit. Norm - Praxis - Repräsentation (Cologne 2013) 265-272. 
Carl, Horst, 'Landfriedensbrecher und "Sicherheitskräfte". Adlige Fehdeführer und Söldner im 16. Jahrhundert', in Christoph Kampmann and Ulrich Niggemann (eds.), Sicherheit in der Frühen Neuzeit. Norm - Praxis - Repräsentation (Cologne 2013) 273-287.

Carl, Horst, 'Kollektive Sicherheit und föderative Ordnung - die Eidgenossenschaft und die Niederlande in der Frühen Neuzeit', in Irene Dingel, Johannes Paulmann, Matthias Schnettger, and Martin Wrede (eds.), Theatrum Belli - Theatrum Pacis. Konflikte und Konfliktregelungen im frühneuzeitlichen Europa (Göttingen 2018) 25-37.

Carl, Horst, Rainer Babel, and Christoph Kampmann, 'Einleitung. Sicherheitsprobleme im 16. und 17. Jahrhundert. Bedrohungen, Ambivalenzen, Konzepte im französischen-deutschen Vergleich', in Horst Carl, Rainer Babel, and Christoph Kampmann (eds.), Sicherheitsprobleme im 16. und 17. JahrhundertBedrohungen, Konzepte, Ambivalenze/Problèmes de sécurité aux XVIe et XVIIe siècles - Menaces, concepts, ambivalences (Baden-Baden 2019) 9-26.

Contamine, Philippe, La guerre en Moyen Age (Paris 1980).

Conze, Eckart, Geschichte der Sicherheit. Entwicklung - Themen - Perspektiven (Göttingen 2018).

Cruickshank, C.G., Elizabeth's army (Oxford 2nd ed. 1966).

Dauven, Bernard, 'L'évolution des pratiques des forces de lordre dans la désignation d'une nouvelle population dangereuse. L'incrimination du vagabondage', Working paper La fabrique de populations problématiques par les politiques publiques (2007), http://www.msh.univ-nantes.fr/servlet/com. univ.collaboratif.utils.LectureFichiergw\%3FCODE_FICHIER=1180950971313\&ID_FICHE $=1327$ (Accessed on 26 April 2019).

Diegerick, I.L.A., Inventaire analytique et chronologique des chartes et documents appartenant aux archives de la ville d'Ypres, 7 vols. (Bruges: Vandecastele Werbrouck, 1853-1868).

De Kempenare, P., Vlaemsche kronijk, of dagregister van al het gene gedenkweerdig voorgevallen is, binnen de stad Gent, sedert den 15 july 1566 tot 15 juni 1585. P. Blommaert (ed.) (Ghent: L. Hebbelynck, 1839).

Devillers, Leopold, Inventaire analytique des archives des États d'Hainaut, 3 vols. (Mons: Hector Manceaux, 1884-1906).

Egmond, Florike, Underworlds. Organized crime in the Netherlands, 1650-180o (Cambridge 1993).

Fierke, K.M., Critical approaches to international security (Cambridge $2^{\text {nd }}$ ed. 2015).

Gunn, Stephen, David Grummitt, and Hans Cools, War, state and society in England and the Netherlands, 1477-1559 (Oxford 2007).

Hammer, Paul E.J., Elizabeth's wars. War, government and society in Tudor England, 1544-1604 (Basingstoke 2003).

Härter, Karl, 'Grenzen, Streifen, Pässe und Gesetze. Die Steuerung von Migration im frühneuzeitlichen Territorialstaat des Alten Reiches (1648-1806)', in Jochen Oltmer (ed.), Handbuch Staat und Migration in Deutschland seit dem 17. Jahrhundert (Berlin 2015) 45-86.

Hasselt, Gerard van, Kronijk van Arnhem (Arnhem: W. Troost en zn., 1790).

Hasselt, Gerard van, Geldersche oudheden (Arnhem: J.H. Moeleman Jr., 1806).

Het Tweede Deel vande placcaerten, ordonnantien ende edicten van de hertoghen van Brabandt, princen van dese Nederlanden (Brussels: Joseph Ermens, 1775).

Het tweede protest (s.1. 1702).

Huntebrinker, Jan Willem, “"Gartknecht” und "Passport”. Zum Problem von Mobilität, Zugehörigkeit und Kontrolle (15.-17. Jahrhundert)', Working Papers des Arbeitskreises Policey/Polizei in der Vormoderne 14 (2007), https://www.univie.ac.at/policey-ak/pwp/pwp_14.pdf_(Accessed on 26 December 2018).

Kintzinger, Martin, 'Brigands. Gewaltformationen in französischen Spätmittelalter', in Winfried Speitkamp (ed.), Gewaltgemeinschaften. Von der Spätantike bis ins 20. Jahrhundert (Göttingen 2013) 75-102.

Lanzinner, Maximilian, 'Ein Sicherheitssystem zwischen Mittelalter und Neuzeit. Die Landfriedens- und Sonderbünde im Heiligen Römischen Reich', in Christoph Kampmann and Ulrich Niggemann (eds.), Sicherheit in der Frühen Neuzeit. Norm - Praxis - Repräsentation (Cologne 2013) 99-119.

Loon, W. van, Gelders placaet-boeck, inhoudende de placaeten ende ordonnantien, soo by wylen keyser Kaerle en coninck Philips als hertogen van Gelre ende graven van Zutphen, als by de edele mogende heeren Staeten 
des furstendoms Gelre ende Graeffschaps Zutphen, sedert den jaere 1543. tot den jaere 170o. uytgegeven, 3 vols. (Nijmegen: Suerus van Goor, 1701).

Mallett, Michael, 'Mercenaries', in Maurice Keen (ed.), Medieval warfare. A history (Oxford 1999) 209-229.

Mol, Hans, and Peter van der Meer, De Friese volkslegers tussen 1480 en 1560 met een editie van de monsterlijsten van Friesland 1552 en Ameland 1558 (Hilversum 2017).

Nassiet, Michel, La violence, une histoire sociale. France, xvie-xviiie siècles (Seyssel 2011).

Nicholson, Helen, Medieval warfare. Theory and practice of war in Europe, 300-1500 (Basingstoke 2004).

Nickle, Barry Harold, The military reforms of Prince Maurice of Orange. PhD diss., University of Delaware, 1975.

Nijenhuis, Ida, et al. (eds), Besluiten Staten-Generaal 1626-1630, http://resources.huygens.knaw.nl/besluitenstatengeneraal1576-1630/BesluitenStaten-generaal1626-1651 (Accessed on 30 April 2020).

Nordman, D., 'Sauf-Conduits et passeports, en France, à la Renaissance', in Jean Céard and Jean-Claude Margoline (eds.), Voyager à la Renaissance (Paris 1987) 145-158.

Os, Peter van, Kroniek van Peter van Os. Geschiedenis van 's-Hertogenbosch en Brabant van Adam tot 1523, A.M. van Lith-Droogleever Fortuijn, J.G.M. Sanders, and G.A.M. van Synghel (eds.) (The Hague 1997).

Parker, Geoffrey, The Army of Flanders and the Spanish Road, 1567-1659. The logistics of Spanish victory and defeat in the Low Countries' wars (Cambridge 2nd ed. 2004).

Piceu, Tim, Over vrybuiters en quaetdoenders. Terreur op het Vlaamse platteland (eind 16de eeuw) (Louvain 2008).

Paulus, Pieter, Verklaring der Unie van Utrecht, 4 vols. (Utrecht: J. van Schoonhoven and comp., 1776).

Placcaet ende Ordonnantie Ons Ghenaedichs Heeren des Conincx, Tegens het volck van oirloge, soo te voete als te peerde, wesende inden dienst ende besoldinge van zyne Majesteyt, die verlaeten den leger, heure vendelen ende garnisoenen daer zy liggen, sonder oirloff ende passepoort (Brussels: R. Velpius, 1592).

Postma, Folkert, 'De mislukte missie van mr. Maarten van Naarden als luitenant-stadhouder van Stad en Lande 1541-1557', BMGN/Low Countries Historical Review 120 (2005) 1-27.

Pröve, Ralf, 'Gewaltformen in frühneuzeitlichen Lebenswelten', in Winfried Speitkamp (ed.), Gewaltgemeinschaften. Von der Spätantike bis ins 20. Jahrhundert (Göttingen 2013) 149-161.

Recueil des ordonnances des Pays Bas. 2série, 1506-170o. Ch. Laurent, J. Lameere, and H. Simont (eds.), 8 vols. (Brussels 1893-1978).

Register gehouden by meester Aert vander Goes, advocat van de Staten 's Lands van Hollandt, van alle die dachvaerden by deselve staten gehouden, mitsgaders die resolutien, propositien, ende andere gebesongneerde in de voirsz dachvaerden gedaen 6 vols. ([The Hague]: s.d. [1750]).

Register van Holland en Westvriesland (The Hague: 1574-1781).

Reitsma, Rients, Centrifugal and Centripetal Forces in the Early Dutch Republic. The States of Overijssel, 1566-1600 (Amsterdam 1982).

Resolutiën der Staten-Generaal van 1576 tot 1609. N. Japikse and H.H.P Rijperman (eds.), 14 vols. (The Hague: Martinus Nijhoff, 1915-1970).

Resolutiën der Staten-Generaal van 1610 tot 1670. A.Th. van Deursen, J.G. Smit, and J. Roelevink (eds.), 7 vols. (The Hague 1971-1994).

Rethaan Macaré, C.A. (ed.), 'Dagverhaal van den veldtogt van keizer Karel v in 1554', Kronijk van het Historisch Genootschap 7 (1851) 280-308.

Reusch, Marius Sebastian, “Bedrohliche Mobilität”. Das Problem der "Gartknechte” für die Landfriedenswahrung im Südwesten des Alten Reiches im 16. Jahrhundert', in Hendrik Baumbach and Horst Carl (eds.), Landfrieden - Epochenübergreifend. Neue Perspektiven der Landfriedensforschung auf Verfassung, Recht, Konflikt (Berlin 2018) 209-231.

Rinzema, A.J., Sicke Benninge en zijn kroniek. Een Groninger burger over opkomst en verval van zijn stad rond 1500 (The Hague 2014).

Robaulx de Soumoy, A.L.P. de, Étude historique sur les tribunaux militaires en Belgique (Brussels 1858).

Ruff, Julius R., Violence in Early Modern Europe, 1500-1800 (Cambridge 2001).

Schnerb, B., 'L'honneur de la maréchaussée'. Maréchalat et maréchaux en Bourgogne des origines à la fin du Xve siècle (Turnhout 2000). 
Schorn-Schütte, Luise, 'Sicherheit als Begriff und Phänomen in der Europäischen Frühen Neuzeit - Einleitung in die Sektion', in Christoph Kampmann and Ulrich Niggemann (eds.), Sicherheit in der Frühen Neuzeit. Norm - Praxis - Repräsentation (Cologne 2013) 43-46.

Schwartzenberg and Hohenlansberg, G.F. thoe, Groot placaat en charter-boek van Vriesland, 5 vols. (Leeuwarden: Willem Coulon, 1768-1793).

Swart, Erik, Krijgsvolk. Militaire professionalisering en het ontstaan van het Staatse leger, 1568-159o (Amsterdam 2006).

Tracy, James D., The founding of the Dutch Republic. War, finance, and politics in Holland, 1572-1588 (Oxford 2008).

Tweeden druck vanden eersten bouck der ordonnancien, statuten, edicten ende placcaerten, soo van weghen der keyserlyke ende koninghlyke maiesteyten, als hevrlieder doorlvghtighste voorsaeten, graven ende graefneden van Vlaendren, nievwelinghs vermeerdert met doorgaende marginale aenwysinghen ende volkommentafel (Ghent: Anna vanden Steene, 1639).

Tweeden placaet-bovck, inhoudende diversche ordonnancien, edicten ende placaeten vande coninclicke ma.ten ende haere deurluchtige hoocheden, graven van Vlaendren, metsgaders van heurliederen Provincialen Raede aldaer, ghepubliceert inden voorghenoemden Lande van Vlaendren t'zedert den iaere vyfthien-hondert t'zestich, tot ende metten iaere zesthien-hondert neghenen-twintich (Ghent: Anna vanden Steene, 1629).

Vanhemelryck, Fernand, De criminaliteit in de ammanie van Brussel van de late middeleeuwen tot het einde van het Ancien Régime (1404-1789) (Brussels 1981).

Vanhemelryck, Fernand, Marginalen in de geschiedenis. Over beulen, joden, hoeren, zigeuners en andere zondebokken (Louvain 2004).

Veen, J.S. van, 'De boerenopstanden van 1580', Bijdragen en Mededelingen Gelre 16 (1913) 61-70.

Vivere, Jan van den, Chronijcke van Ghendt door Jan van den Vivere en eenige andere aanteekenaars der XVIe en Xvire eeuw. Frans De Potter (ed.) (Ghent: S. Leliaert, A. Siffer \& Cie, 1885).

Water, Johan van de, Groot placaatboek vervattende alle de placaten, ordonnantien en edicten der edel moogende heeren Staten 'slands van Utrecht, mitsgaders van de ed. groot achtb. heeren borgemeesteren en vroedschap der stad Utrecht, tot het jaar 1728 ingesloten, 3 vols. (Utrecht: J. van Poolsum, 1729).

Weber, Sascha, 'Landfriedenspolitik im Schwäbischen Kreis. Vom Ende des Schwäbischen Bundes bis zum Vorabend des Dreißigjährigen Krieges', in Hendrik Baumbach and Horst Carl (eds.), Landfrieden - Epochenübergreifend. Neue Perspektiven der Landfriedensforschung auf Verfassung, Recht, Konflikt (Berlin 2018) 185-207.

Wilson, Peter H., 'Securitization in the Holy Roman Empire 1495-1806', in Horst Carl, Rainer Babel, and Christoph Kampmann (eds.), Sicherheitsprobleme im 16. und 17. Jahrhundert - Bedrohungen, Konzepte, Ambivalenze/Problèmes de sécurité aux xvie et XviIe siècles - Menaces, concepts, ambivalences (BadenBaden 2019) 59-90.

Zijp, A., De strijd tusschen de Staten van Gelderland en het Hof 1543-1566 (Arnhem 1913). 